\title{
TURNOVER OF LABELED NORMAL GAMMA GLOBULIN IN MULTIPLE MYELOMA *
}

\author{
By STUART W. LIPPINCOTT, SAMUEL KORMAN, $\dagger$ CONRAD FONG, \\ ELMER STICKLEY, WILLIAM WOLINS AND \\ WALTER L. HUGHES
}

(From the Medical Department, Brookhaven National Laboratory, Upton, N. Y.)

(Submitted for publication September 16, 1958; accepted December 4, 1959)

Aberrations of protein metabolism in multiple myeloma have been studied by a number of investigators $(1-6)$ to ascertain whether the globulins in the blood consist of excesses of normal globulins or of chemically abnormal globulins, or both. Such research has been directed toward determining whether "characteristic protein abnormalities" could be distinguished by 1 ) separation of the serum proteins with identification of their physicochemical properties by using the Tiselius electrophoresis apparatus and the analytical ultracentrifuge ; 2 ) certain structural relationships indicated by the amino end-group method; 3) immunochemical procedures; and 4) detection of formation of abnormal protein by administering to the patient isotopically labeled amino acids, the tracers being the stable isotopes $\mathrm{N}^{15}$ and $\mathrm{C}^{13}$ or radioactive carbon, $\mathrm{C}^{14}$. By use of such experimental methods it has been reported that at least some, if not all, of the quantitatively excessive globulins produced in this disease are abnormal.

Our approach to the investigation of certain fundamental aspects of protein metabolism in this disease has been concerned with the patient's turnover of globulins. Data are being presented which were obtained by determining the biological half-life of gamma globulin fractionated from normal individuals, labeled with $\mathrm{I}^{131}$ and injected into ten patients with clinically proven multiple myeloma. A subsequent report will be devoted to the findings when the source of the fractionated gamma globulin was from patients with multiple myeloma. The latter study permitted observations on the half-life of labeled autologous and homologous preparations in this disease.

The electrophoretic pattern of the serum of each

* This research was supported by the United States Atomic Energy Commission.

$\dagger$ Research Collaborator from the Montefiore Hospital, New York, N. Y. patient was determined to establish the presence of a predominant and characteristic peak. It has been stated previously by others (7-9) that a sharply defined peak is due to the presence of large amounts of anomalous protein components. Because of the similarity in mobility of these peaks to those of the corresponding normal serum protein components, the peaks have been designated by the normal appellation. Six categories have been reported in this disease : alpha type, beta type, gamma type, $M$ peak migrating between the gamma and beta peaks, multiple peaks, and minor anomalies. It has been categorically stated in some of the literature referred to above that for a given case the abnormal protein retains the same electrophoretic mobility throughout the course of the patient's disease. Data substantiating this statement are difficult to find, but there is one study $(10)$ in which the protein distribution was followed by electrophoresis for one to three years in six patients with this disease. In four of these cases there was a persistence of the same peak with time, and in each instance there was with time an increase in the amount of the anomalous protein. In two other cases in this group, the final well established peak was hardly noticeable earlier in the course of the disease, but with time it became prominent. For our purposes the patients' electrophoretic diagram before the time of injection of the labeled normal gamma globulin was determined. These patients are shown in Figures $1 \mathrm{~A}$ and $\mathrm{B}$ and include in some instances patterns made about three to six months apart. The halflife of the individual globulin turnover has been considered both separately and with reference to the protein distribution in the serum as indicated by the electrophoretic pattern.

\section{PATIENTS AND METHODS}

Source and preparation of normal gamma globulin which was injected after labeling. The gamma globu- 


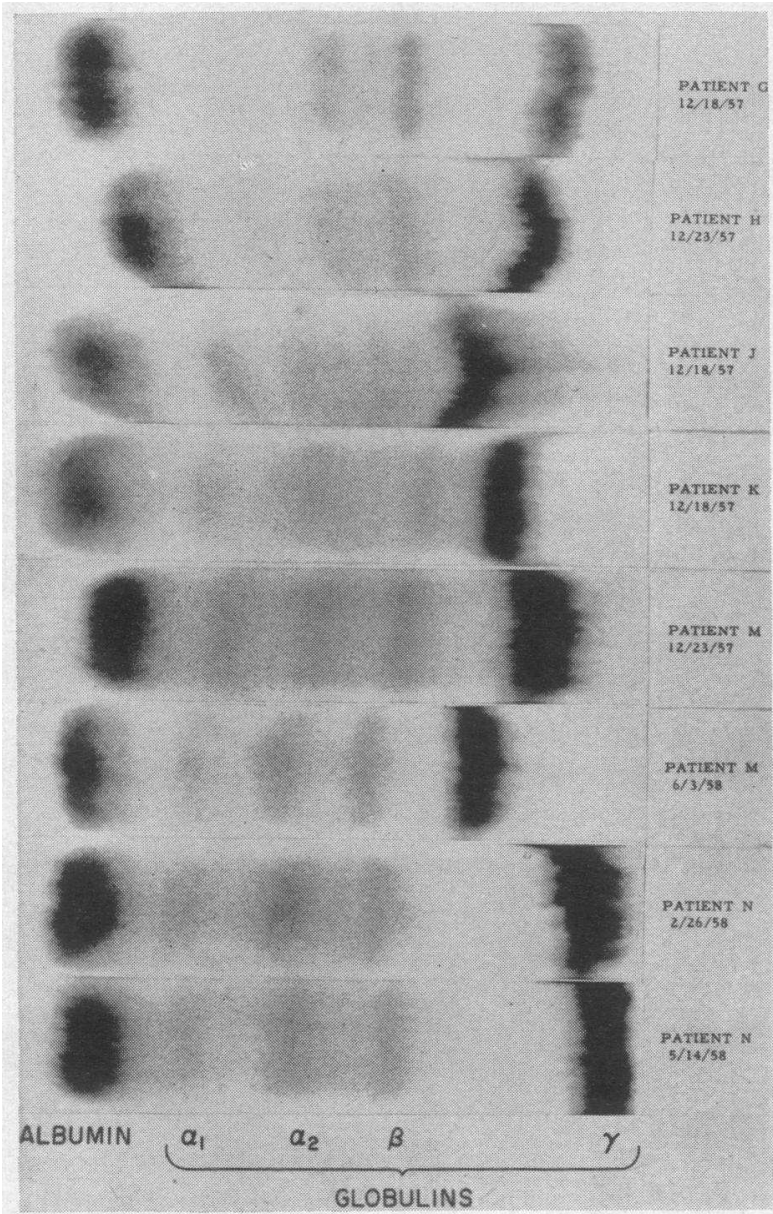

Fig. 1A. Serum PAPER electrophoretic Pattern With GAMMA PEAK IN PATIENTS WITH MULTIPLE MYeloma.

lins used for turnover studies were prepared from individual serums by the method of Nichol and Deutsch (11); the serum was diluted with 3 vol of cold distilled water and adjusted to $\mathrm{pH} 7.7$ by the addition of $0.05 \mathrm{M} \mathrm{CH}_{3}$ $\mathrm{COOH}$ or $\mathrm{Na}_{2} \mathrm{HPO}_{4}, 50$ per cent ethanol was then added slowly with stirring to a final concentration of 20 per cent (vol/vol), the temperature being simultaneously decreased to $-5^{\circ} \mathrm{C}$. After standing about an hour, the precipitate was centrifuged and resuspended in 10 to 20 vol of water at $0^{\circ} \mathrm{C}$ and the $\mathrm{pH}$ adjusted to 5.1 by the addition of $0.05 \mathrm{M}$ acetic acid. Fifty per cent ethanol was then slowly added to $0^{\circ} \mathrm{C}$ to give a final concentration of 15 per cent and after standing about an hour, the precipitate was centrifuged off and stored at $-20^{\circ} \mathrm{C}$ for possible future fractionation. The supernatant was adjusted to $\mathrm{pH} 5.6$ by the addition of $0.05 \mathrm{M} \mathrm{Na}_{2} \mathrm{HPO}_{4}$ and 50 per cent ethanol was added to a final concentration of 12 per cent at $-3.5^{\circ} \mathrm{C}$. This precipitate was also removed and stored for possible future use. The gamma globulin remaining in the supernatant was precipitated by adjusting the $\mathrm{pH}$ to 7.3 by the addition of $0.05 \mathrm{M} \mathrm{Na}_{2} \mathrm{HPO}_{4}$ followed by the addition of 50 per cent ethanol to a final concentration of 25 per cent. After centrifuging, the precipitated gamma globulin (ppt. C-2- $\gamma^{2}$ globulin by the designation of Nichol and Deutsch) was suspended and dialyzed against distilled water overnight and dried from the frozen state. The yield approximated $400 \mathrm{mg}$ per $100 \mathrm{ml}$ of normal serum. The products contained only gamma globulin as judged by electrophoretic (Tiselius) analysis.

The electrophoretic characterization of this chemical fraction was carried out in the commonly used $\mathrm{pH} 8.6$ barbital buffer in a standard Tiselius apparatus at a bath temperature of $0^{\circ} \mathrm{C}$, a field strength of 8.9 volts per $\mathrm{cm}$, and a protein concentration of about 1 per cent. After variable periods of runs up to 180 minutes, the patterns were recorded by the Longsworth scanning method. In each of the preparations used for labeling, more than 95 per cent of the protein traveled in a single Gaussian envelope with the mobility of gamma globulin. Before administration each preparation was passed through Seitz filters and cultured for sterility. Two donor sources, a 34 year old female and a 35 year old male, provided the blood for fractionation. Each was an asymptomatic volunteer, hospitalized and, after being extensively studied, considered as a suitable healthy donor. The establishment of "normality" was considered important because in subsequent studies the globulins were prepared from patients with multiple myeloma and thus could differ chemically or structurally.

Labeling of gamma globulin with radioactive iodine. Iodination was carried out following the principles established for the iodination of serum albumin by Hughes and Straessle (12); 100 to $150 \mathrm{mg}$ of gamma globulin was dissolved in 1 to $2 \mathrm{ml}$ of $0.01 \mathrm{~N} \mathrm{NH}_{4} \mathrm{OH}$ at $0^{\circ} \mathrm{C}$. The iodinating reagent was prepared by adding 1 drop

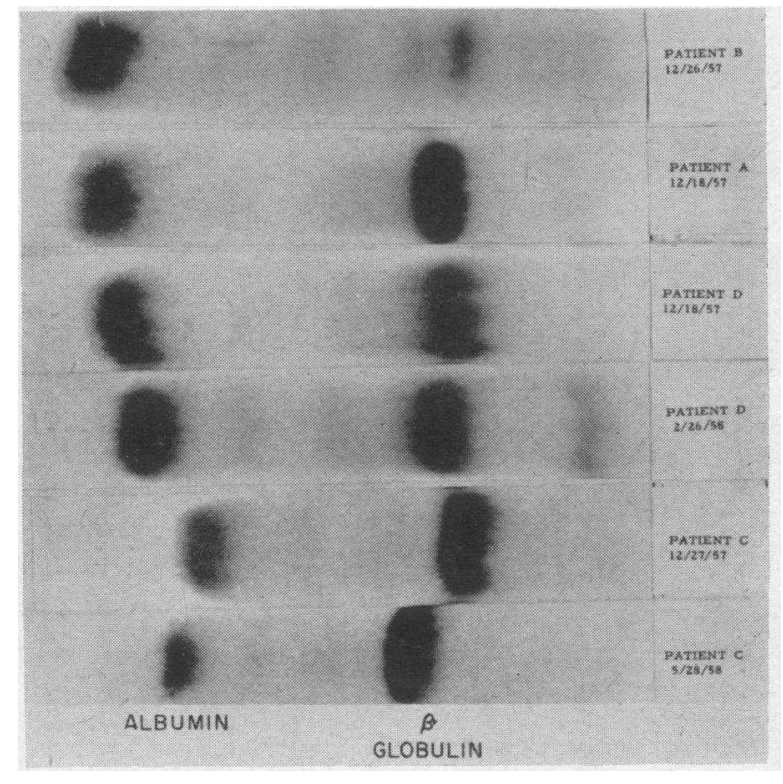

Fig. 1B. SERUM PAPER eleCtropHORETIC PATtERN WITH BETA PEAK IN PATIENTS With MULTIPLE MYeloma. 
of $1 \mathrm{~N} \mathrm{HCl}$ to the required number of millicuries (usually about 6) of $\mathrm{I}^{131}$ obtained from Oak Ridge and an amount of iodine dissolved in KI (composition about $\mathrm{K}_{2} \mathrm{I}_{4}$ ) equivalent to 5 moles per mole of protein (assumed $\mathrm{mol} \mathrm{wt}=150,000$ ). If appreciable decolorization of the iodine occurred, it was attributed to the sulfite preservative in the Oak Ridge iodine and subsequent yields were correspondingly low. The iodinating reagent was added slowly to the cold protein solution with continuous stirring and then allowed to stand for about 1 hour. Then it was passed slowly through two anion exchange columns (Abbott ioresin) of about $2 \mathrm{ml}$ in volume to remove unbound iodine (iodide), the protein retained in the column being displaced by water and dialyzed overnight against cold isotonic sodium chloride. The preparations were diluted to a working volume and sterilized by passage through an asbestos filter of the Seitz type, and sterility proved by culture. Over 98 per cent of the radioactivity was precipitable by trichloroacetic acid. The yield was essentially quantitative in terms of the protein and from 5 to 8 per cent in terms of the radioactivity.

Patients. Ten patients with multiple myeloma were investigated. All diagnoses were established by microscopic examination of bone marrow aspirations. Chemical determinations of the serum proteins, paper electrophoretic serum patterns and $\mathrm{X}$-ray bone surveys were also concordant with the diagnoses. The age of the patients ranged from 43 to 80 years and included both sexes and white as well as Negro individuals.

Radioactive assay. Counting was done in a well-type scintillation counter using a 2 inch $\mathrm{NaI}(\mathrm{T} 1)$ crystal and standard electronic components. Duplicate $1 \mathrm{ml}$ samples of serum were contained in ordinary $15 \times 75 \mathrm{~mm}$ glass vials after simple separation in a centrifuge. Aliquots of the original solutions appropriately diluted were carried through the counting program for each experiment and all data are referred to these standards and reported as a percentage of the original dose. This of course automatically corrects for radioactive decay. By consideration of counting rates and background measurements, the counting error for the first part of the experiments was held to 1 per cent, while in the later points, the sample error approached 4 per cent at the lowest counting rates used.

Radiation dosage. In these experiments the intravenously administered radioactivity ranged from 7.5 to 22.1 $\mu \mathrm{c}$. The maximal total dose was calculated to be 0.013 rads in a $50 \mathrm{~kg}$ patient, assuming an effective half-life of 4.3 days and taking the blood as the critical organ (13). Lugol's solution was started 3 days before injection of the labeled protein and given daily throughout the study to prevent thyroid accumulation of radioactive iodine if any were liberated from the compound. The attempt was made to use the smallest feasible quantities of radioactive label and to obtain maximal benefit of improvements in counting procedures and sampling techniques.

Serum electrophoresis. The paper electrophoresis was

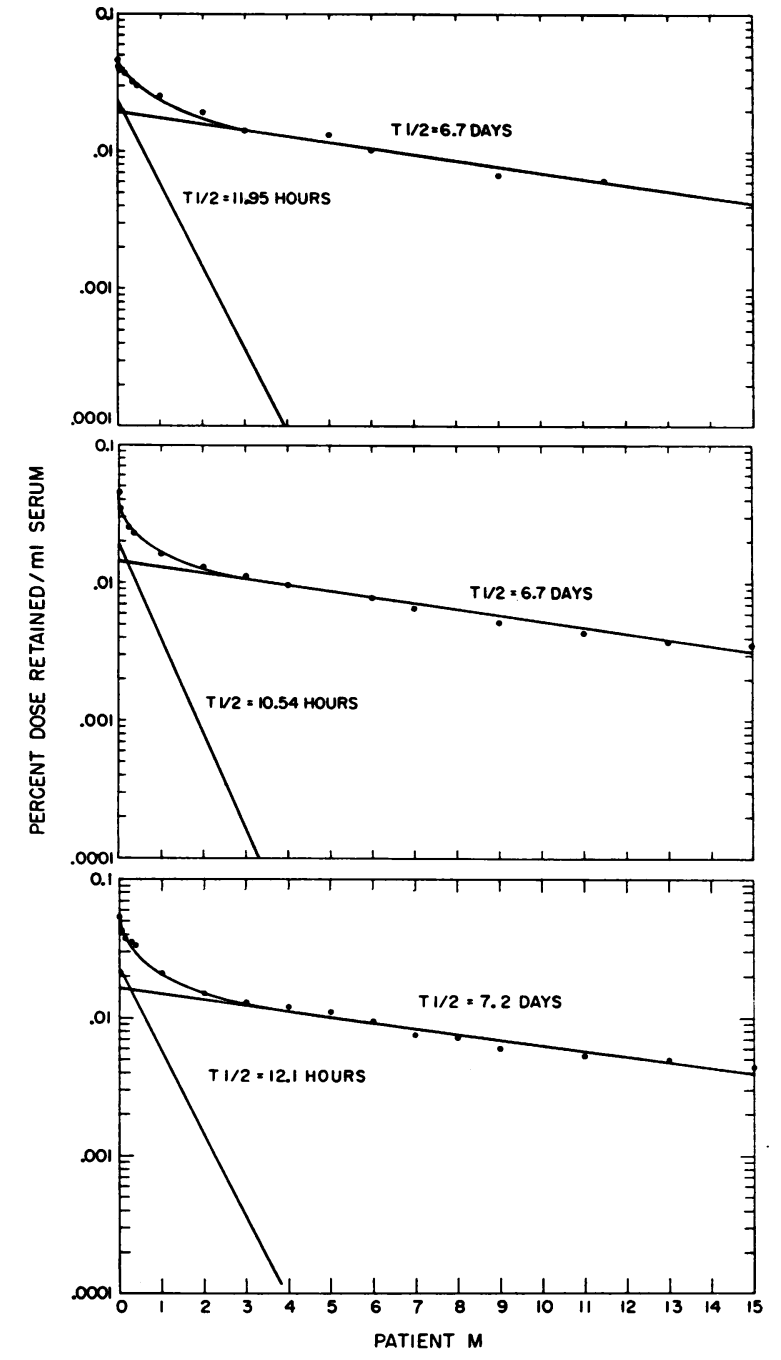

Fig. 2. Semilogarithmic plots of three disappeakANCE CURVES OF $\mathrm{I}^{131}$-LABELED NORMAL GAMMA GLOBULIN. From the sera of hypergammaglobulinemic Patient $M$ with multiple myeloma in whom three turnover studies were made during a six month period.

performed at $\mathrm{pH} 8.6$ in a barbiturate buffer having an ionic strength of 0.05 . The Whatman $1 \mathrm{MM}$ paper strips were moistened with the buffer and placed in the electrophoretic apparatus which was then equilibrated for at least one-half hour. Ten $\lambda(0.01 \mathrm{ml})$ of serum was placed on the Spinco applier with a micropipet and applied in a line transverse to the length of the filter paper. For 10 paper strips which were run in parallel, optimal separations were obtained with 150 to $170 \mathrm{v}$ and $7 \mathrm{ma}$ for 16 hours. The strips were dried in the oven at $110^{\circ} \mathrm{C}$ for 30 minutes and stained with 1 per cent bromphenol-blue in 95 per cent ethanol for 15 minutes. The strips were then washed 3 times in 1 per cent acetic acid baths. After drying at room temperature, the color intensity 
TABLE I

Single turnover of normal I I31-labeled gamma globulin in patients with multiple myeloma

\begin{tabular}{|c|c|c|c|c|c|c|c|}
\hline Donor & Patient & $\begin{array}{l}\text { Patient's serum } \\
\text { electrophoretic } \\
\text { pattern }\end{array}$ & $\underset{\text { I } 181}{\text { Dose }}$ & $\begin{array}{l}\text { Globulin } \\
\text { injected }\end{array}$ & $\begin{array}{l}\text { Duration of } \\
\text { experiment }\end{array}$ & $\begin{array}{c}\text { Start of } \\
\text { experiment }\end{array}$ & $\begin{array}{c}T_{\xi} \text { slow } \\
\text { component }\end{array}$ \\
\hline & & & $\mu c$ & $m g$ & days & & days \\
\hline I & $\mathrm{D}$ & Beta type & 22.1 & 6 & 18 & $11 / 1 / 57$ & 14.6 \\
\hline I & A & Beta type & 22.1 & 6 & 18 & $11 / 1 / 57$ & 18.2 \\
\hline II & B & Beta type & 7.5 & 7 & 12 & $11 / 20 / 57$ & 17.5 \\
\hline II & C & Beta type & 7.5 & 7 & 12 & $11 / 20 / 57$ & 19.0 \\
\hline II & $\mathbf{K}$ & Gamma type & 7.5 & 7 & 12 & $11 / 20 / 57$ & 5.7 \\
\hline II & $\mathbf{M}$ & Gamma type & 7.5 & 7 & 12 & $11 / 20 / 57$ & 6.7 \\
\hline II & $\mathrm{J}$ & Gamma type & 7.5 & 7 & 12 & $11 / 20 / 57$ & 6.7 \\
\hline II & $\mathrm{G}$ & Gamma type & 7.5 & 7 & 12 & $11 / 20 / 57$ & 7.2 \\
\hline II & $\mathrm{H}$ & Gamma type & 7.5 & 7 & 12 & $11 / 20 / 57$ & 8.2 \\
\hline II & $\mathbf{N}$ & Gamma type & 7.5 & 7 & 12 & $11 / 20 / 57$ & 8.9 \\
\hline
\end{tabular}

could be accentuated by exposing the strips over ammonia vapor.

Analyses of data. The method for determining the half-life from the serum concentration curve is demonstrated in Figure 2. The activity remaining was plotted as a function of the time of sampling on semilogarithmic paper. The plotted points were arrived at by comparing the counting rate of the particular sample with the counting rate of the initially administered tracer as represented by its diluted aliquot. To establish the biological half-life of the globulins, straight-line parameters were fitted to the data by the method of least squares, starting with the third day. The rapid early decay of the curve is considered to represent distribution and mixing processes. The decline indicated by the second part of the curve, the slow component, is an exponential decay indicated by the straight line derived in all cases. This exponential decay is believed to represent the rate of degradation of the injected gamma globulin.

The activity found in the daily urinary output has been expressed in two ways: 1) as the percentage of the original dose excreted daily, corrected only for physical decay, and 2) as the ratio of the percentage excreted daily to that remaining in the body on that day. The first method of calculation is referred to as the excretion rate and the second as the degradation rate. From the first procedure the cumulative urinary excretion for any period of days may be determined. No determinations were made of radioactivity appearing in the stool although it has been reported (14) that for $I^{121}$-labeled albumin, fecal excretion can account for as much as 2.5 per cent of that excreted in the urine and, in addition, that up to 3 per cent of the radioactivity may be withdrawn during blood sampling in the course of a study. Thus the assumption is that about 95 per cent or more of all the radioactivity lost from the body is recovered in the urine. Incompleteness of urinary collections, as in bed patients voiding into a bed pan, must be taken into consideration in evaluating excretion data. An additional computation described (14) as a "distribution curve" was determined by dividing the serum concentration curve by the percentage of activity retained in the body. According to these authors the significance of a horizontal asymptote in the distribution curve is twofold: 1) it offers evidence that during the entire period of study, radioiodine released from degraded protein is almost completely recovered in the urine; and 2) it further indicates that any change in the slope of the plasma concentration curve after the distribution curve has become horizontal must be due to a change in the apparent rate of degradation and is not to be explained by distribution or storage phenomena. Degradation rates determined from two independent sets of data, plasma concentrations, and urinary excretions may thus be compared.

\section{RESULTS}

The serum electrophoretic patterns of the patients with multiple myeloma are shown in Figures $1 \mathrm{~A}$ and $\mathrm{B}$. In four of these (B) the predominant peak was of the beta type and in the

TABLE II

Repeated turnovers of normal $I^{131}-$ labeled gamma globulin in patients with multiple myeloma

\begin{tabular}{|c|c|c|c|c|c|c|c|c|c|c|}
\hline $\begin{array}{l}\text { Donor } \\
\text { Patient } \\
\text { Electrophoretic pattern } \\
\text { Dose I'131, } \mu \mathrm{c} \\
\text { Mg } \gamma \text {-globulin injected }\end{array}$ & $\begin{array}{l}\text { II } \\
\text { C } \\
\text { Beta } \\
7.5 \\
7\end{array}$ & $\begin{array}{l}\text { II } \\
\text { C } \\
\text { Beta } \\
20.0 \\
10\end{array}$ & $\begin{array}{l}\text { II } \\
\text { C } \\
\text { Beta } \\
21.8 \\
5.3\end{array}$ & $\begin{array}{l}\text { II } \\
\text { Gamma } \\
\underset{7}{7.5}\end{array}$ & $\begin{array}{l}\text { II } \\
\text { M } \\
\text { Gamma } \\
20.0 \\
10\end{array}$ & $\begin{array}{l}\text { II } \\
\text { M } \\
\text { Gamma } \\
21.8 \\
5.3\end{array}$ & $\underset{7.5}{\text { II }} \underset{7}{\text { Gamma }}$ & $\begin{array}{l}\text { II } \\
\text { G } \\
\text { Gamma } \\
21.8 \\
5.3\end{array}$ & $\begin{array}{l}\text { II } \\
\text { Gamma } \\
7.5 \\
7\end{array}$ & $\begin{array}{l}\text { II } \\
\text { Namma } \\
\text { Gamm } \\
\mathbf{1 4 . 5} \\
\mathbf{3 . 5}\end{array}$ \\
\hline $\begin{array}{l}\text { days } \\
\text { Date start of experiment }\end{array}$ & $11 / 20 / 57$ & $\begin{array}{l}17 \\
5 / 1 / 58\end{array}$ & $\begin{array}{l}16 \\
5 / 29 / 58\end{array}$ & $\frac{12}{11 / 29 / 57}$ & $\begin{array}{l}17 \\
5 / 1 / 58\end{array}$ & $\begin{array}{l}16 \\
5 / 29 / 58\end{array}$ & 12 11/20/57 & $\begin{array}{l}16 \\
5 / 29 / 58\end{array}$ & $\begin{array}{l}12 \\
11 / 20 / 57\end{array}$ & $\begin{array}{l}17 \\
5 / 28 / 58\end{array}$ \\
\hline days & 19.0 & $11.4^{*}$ & 16.1 & 6.7 & 6.7 & 7.2 & 7.2 & 6.9 & 8.9 & 7.2 \\
\hline
\end{tabular}

* On urethan therapy at this time. 
remaining six (A) of the gamma type. The halflife of each of the slow components is presented in Table I. Two normal donor sources of gamma globulin were utilized and the amount of protein administered was so small that it could not have had any significant effect on the total protein concentration or metabolism in the patient. The amount of $\mathrm{I}^{131}$ used for labeling was sufficient for counting purposes but minimal in amount so that there would be insufficient radiation to degrade the labeled protein and so that the whole-body radiation dose would be considerably below the allowed level of rads for a tracer investigation. The mean of the half-life of the slow component obtained from the serum concentration curves for the beta type was $16.12 \pm 1.15$ days and for the gamma type $7.14 \pm 0.28$ days. $^{1}$ The probability was less than 0.001 when these latter two groups were compared.

Since it is impossible to do replicate testing in determining the accuracy of the method of obtaining the half-life, repeated turnovers were done as is illustrated for one case in Figure 2 and for four cases in Table II. This method offered the additional advantage of further testing the homo-

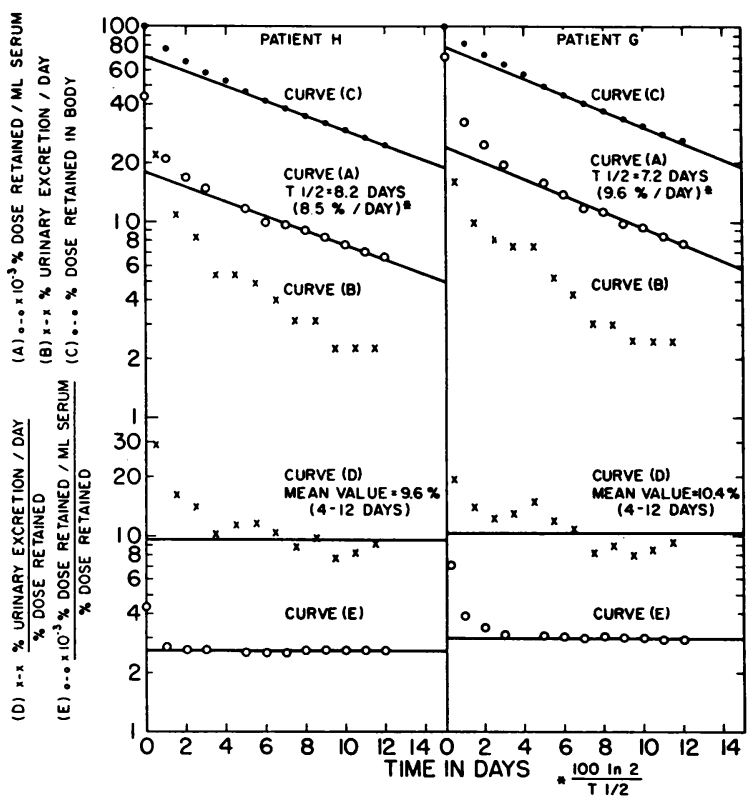

Fig. 3. TURnover of NORMal gamma globulin IN TWO HYPERGAMMAGLOBULINEMIC MULTIPLE MYELOMA PATIENTS.

1 Obtained from Tables I and II.

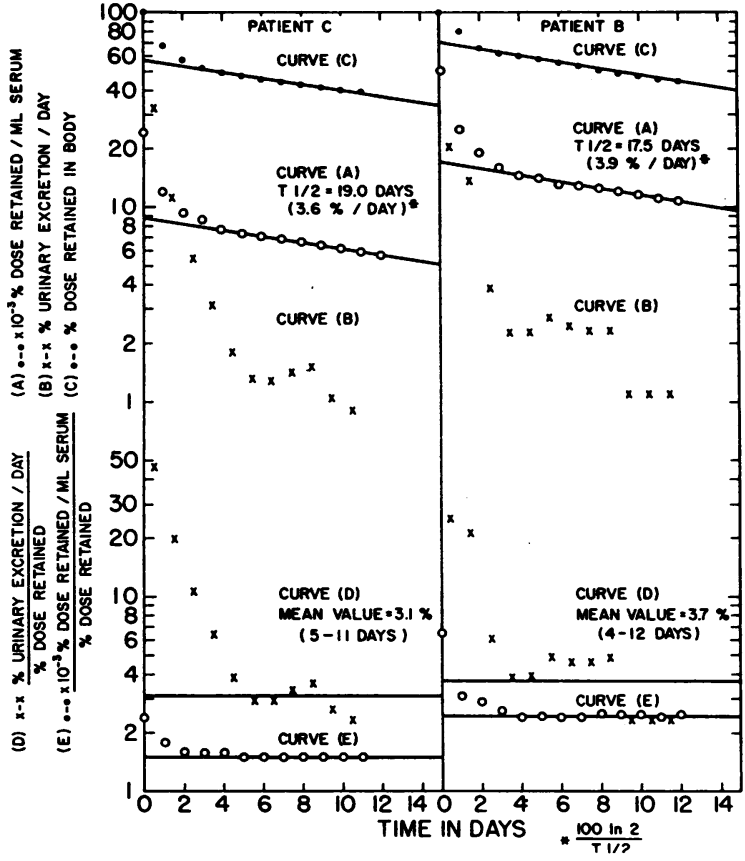

Fig. 4. TURNOVER OF NORMAL GAMMA GLOBULIN IN TWO HYPERBETAGLOBULINEMIC MULTIPLE MYELOMA PATIENTS.

geneity of the globulin preparations and the reproducibility of the iodination technique. In $\mathrm{Pa}$ tients $\mathrm{M}, \mathrm{G}$ and $\mathrm{N}$ the comparative data are quite consistent for the half-life of the slow components. In Patient $\mathrm{C}$ in the slow component the half-life for the second turnover was 11.4 days in contrast to 19 and 16.1 days, respectively, for the first and third turnovers. No explanation for this has been established, but it is of interest that at that time the patient was on urethan therapy.

It has been stated earlier in this paper that the homogeneity of the gamma globulins obtained from fractionation of serum from healthy individuals and utilized in these studies was investigated by determining certain of their physicochemical characteristics. Limited further information on the homogeneity or lack of it in the $\mathrm{I}^{131}$-labeled gamma globulin used for the turnover studies was obtained by determination of the urinary radioiodine excretion in four patients. Two patients had a hypergammaglobulinemia serum pattern (Figure 3) and the other two a hyperbetaglobulinemia pattern (Figure 4 ). The degradation rates determined from the serum concentration curves and the urinary excretions may be 
compared, respectively, in each of the four cases as follows: in Patient H, 8.5 and 9.6 per cent ; in Patient G, 9.6 and 10.4 per cent ; in Patient C, 3.6 and 3.1 per cent ; and in Patient B, 3.9 and 3.7 per cent. Examination of the distribution curves in these four subjects indicates that all conform essentially to a horizontal asymptote.

\section{DISCUSSION}

In a survey of the literature an attempt was made to learn whether, in properly prepared normal gamma globulin, a half-life had been established in normal individuals and in patients with various diseases. Very little information was obtainable. Vaughan and associates (15) reported a half-life of 7.0 to 8.8 days in four "normal" persons and an average of 1.8 days less in four patients with rheumatoid arthritis. Havens, Dickensheets, Bierly and Eberhard (16) studied a group of nine individuals consisting of normal subjects and convalescent patients in whom the half-life was 10.6 to 16.6 days. Eisenmenger and Slater (17) in eight "normals" found a half-life of 11.5 to 19 days and in 25 patients with cirrhosis, 6 to 13 days. In two of these three studies, the halflife for normal individuals ranged from 10.6 to 19 days, somewhat comparable (slightly shorter) to our beta type multiple myeloma patients. In one study the turnover was short, 7.0 to 8.8 , and raises the question of whether or not the labeled protein had undergone degradation. In the two disease states studied, the half-life was markedly shortened as it was in our gamma type multiple myeloma patients.

Serum protein turnover in two patients with multiple myeloma has been studied by Berson and Yalow (18). The serum proteins of a patient with a high serum concentration of gamma myeloma globulin but no Bence Jones proteinuria were labeled with $\mathrm{I}^{131}$ and administered intravenously to this subject as well as to another patient who manifested marked Bence Jones proteinuria but was not considered to demonstrate anomalous serum proteins in his electrophoretic pattern. The half-time of the donor's myeloma protein given to himself was 15.5 days, and in the recipient with the presumably normal serum protein distribution it was 17 days. This experiment differs from ours in that we fractionated normal gamma globulin from the sera of healthy control individuals, labeled it with the same isotope, $\mathrm{I}^{131}$, and determined the half-life of this material in patients with multiple myeloma. Thus we cannot make a comparative statement, but it is of interest that in our patients with a gamma peak demonstrated electrophoretically in the serum, the range of half-life was 5.7 to 8.9 days for normal gamma globulin, while in Berson and Yalow's gamma type myeloma patient, the turnover for the labeled serum myeloma protein was much longer15.5 days. In our unpublished data on six patients with electrophoretic gamma type serum peaks, injected with $\mathrm{I}^{131}$-labeled homologous gamma globulin preparations from patients with multiple myeloma, the range of half-life was 5.5 to 9.2 days. In both of our types of preparations the half-life in patients with a gamma type serum peak was significantly shorter than that in Berson and Yalow's two cases.

Neufeld (19) carried out a study on two patients with multiple myeloma, one with a gamma and the other with a beta type serum electrophoretic pattern. One hundred $\mu \mathrm{c}$ of $\mathrm{I}^{131}$ was added to plasma obtained from each patient so that, according to the author, the patients' own serum proteins were tagged. The patients were injected intravenously with their own iodinated plasma, and blood samples were taken at intervals thereafter through 15 days. Counts in a well-type scintillation counter were made on the samples. The plasma proteins were then separated by repeated electrophoretic runs, the albumin and the lumped globulins were eluted, precipitated and taken into solution to constant volume. The count was taken for each. Semilogarithmic plots of the corrected counts per minute per milliliter of plasma globulins were made against time. In the patients with myelomatosis, the globulins had a shortened disappearance rate with a mean $\mathrm{I}^{131}$ half-life of 7.2 days, as contrasted to 10.6 days for the globulins of normal male adults. The author states that these data suggest a significantly greater rate of turnover of the serum globulins in patients with myelomatosis. In the first patient, 6.7 per cent of his total serum globulin was represented by abnormal gamma globulin, while in the second patient, 72 per cent was in the beta globulin. In our unpublished data on $\mathrm{I}^{131}$-labeled 
gamma globulin, obtained from patients with multiple myeloma, whose half-life was determined autologously and homologously as referred to above, the half-life is in agreement in the gamma type patient with Neufeld's findings.

In evaluating the significance of the difference in half-life of labeled normal gamma globulin in our multiple myeloma patients with beta and gamma type serum electrophoretic patterns, several factors have to be considered. The term "normal gamma globulin" refers to two preparations fractionated from two healthy donors. Even under the best methods of fractionation it is recognized that a small percentage of heterogeneity will be present in the final product used for labeling. The purpose in using physicochemical techniques for studying these preparations is to select what appear to be the best of them. That $\mathrm{I}^{131}$, even in the small amounts used for labeling, may conceivably alter the normal preparations is recognized. Radiation itself from the isotope may affect the protein but in the amounts used in these studies this effect must, at most, be very little. The excretion rates determined in four patients receiving the same labeled globulin indicate a variation in rate which, in the first 24 hours varied from 22.70 per cent in one gamma type individual to 31.66 per cent in a beta type patient. This may be a further indication of some degree of heterogeneity. Finally, 18 was the maximum number of days for which any patient was followed to determine a half-life. If ten times as much tracer $\mathrm{I}^{131}$ had been used in our investigations, the slow component could have been determined in studies extending over a longer period of time. Under such a situation it is conceivable that the half-life in both the beta and gamma type patients might be longer, but it is doubtful that this would alter the significant differences in half-life in both groups.

\section{SUM MARY}

The turnover of I $^{131}$-labeled normal gamma globulin was determined in ten patients with multiple myeloma and correlated with the serum globulin distribution as established by paper electrophoresis. In the beta type individuals the mean of the half-life was $16.12 \pm 1.15$ days, and for the gamma type, $7.14 \pm 0.28$ days. The rate of degradation for normal gamma globulin indicated by the slow component was far more rapid for the patient with excessive gamma globulin in his serum protein distribution than for the individual with excessive beta globulin.

\section{REFERENCES}

1. Putnam, F. W. Aberrations of protein metabolism in multple myeloma. Interrelationships of abnormal serum globulins and Bence-Jones proteins. Physiol. Rev. 1957, 37, 512.

2. Columbia University College of Physicians and Surgeons Combined Staff Clinic. Multiple myeloma. Current clinical and chemical concepts. Amer. J. Med. 1957, 23, 283.

3. Smith, E. L., Brown, D. M., McFadden, M. L., Buettner-Janusch, V., and Jager, B. V. Physical, chemical, and immunological studies on globulins from multiple myeloma. J. biol. Chem. 1955, 216, 601 .

4. Slater, R. J., Ward, S. M., and Kunkel, H. G. Immunological relationships among the myeloma proteins. J. exp. Med. 1955, 101, 85.

5. Putnam, F. W. N-terminal groups of normal human gamma globulin and of myeloma proteins. J. Amer. chem. Soc. 1953, 75, 2785.

6. Grisolia, F. T., and Cohen, P. P. Amino acid analysis of serum proteins in multiple myeloma. Cancer Res. 1953, 13, 851.

7. Adams, W. S., Alling, E. L., and Lawrence, J. S. Multiple myeloma. Its clinical and laboratory diagnosis with emphasis on electrophoretic abnormalities. Amer. J. Med. 1949, 6, 141.

8. Conn, H. O., and Klatskin, G. Filter paper electrophoretic patterns of serum in multiple myeloma. Amer. J. Med. 1954, 16, 822.

9. Eriksen, N., Ellerbrook, L. D., and Lippincott, S. W. Serum protein analysis by electrophoresis and by the Wolfson-Cohn chemical method. Comparative study. Clin. Chem. 1956, 2, 334.

10. Reiner, M., and Stern, K. G. Electrophoretic studies on the protein distribution in the serum of multiple myeloma patients. Acta Haemat. (Basel) 1953, 9, 19.

11. Nichol, J. C., and Deutsch, H. F. Biophysical studies of blood plasma proteins. VII. Separation of gamma-globulin from the sera of various animals. J. Amer. chem. Soc. 1948, 70, 80.

12. Hughes, W. L., Jr., and Straessle, R. Preparation and properties of serum and plasma proteins. XXIV. Iodination of human serum albumin. J. Amer. chem. Soc. 1950, 72, 452.

13. Hine, G. J., and Brownell, G. L., Eds. Radiation Dosimetry. New York, Academic Press Inc. 1956, p. 223.

14. Berson, S. A., Yalow, R. S., Schreiber, S. S., and Post, J. Tracer experiments with $\mathrm{I}^{131}$ labeled hu- 
man serum albumin: Distribution and degradation studies. J. clin. Invest. 1953, 32, 746.

15. Vaughan, J. H., Armato, A., Goldthwait, J. C., Brachman, P., Favour, C. B., and Bayles, T. B. A study of gamma globulin in rheumatoid arthritis. J. clin. Invest. 1955, 34, 75.

16. Havens, W. P., Dickensheets, J., Bierly, J. N., and Eberhard, T. P. The half-life of normal human gamma globulin in patients with hepatic cirrhosis (abstract). J. clin. Invest. 1953, 32, 573.
17. Eisenmenger, W. J., and Slater, R. J. Distribution and decay of $\mathrm{I}^{131}$ tagged albumin and gamma globulin in patients with cirrhosis (abstract). J. clin. Invest. 1953, 32, 564.

18. Berson, S. A., and Yalow, R. S. Serum protein turnover in multiple myeloma. J. Lab. clin. Med. 1957, 49, 386.

19. Neufeld, A. H. A new concept of the metabolism of the pathological proteins in myelomatosis. Canad. J. Biochem. 1957, 35, 977.

\section{ANNOUNCEMENT OF MEETINGS}

The Fifty-Second Annual Meeting of THE AMERICAN SOCIETY FOR CLINICAL INVESTIGATION will be held in Atlantic City, N. J., on Sunday afternoon and evening, May 1, 1960, in the Chalfonte-Haddon Hall (jointly with the AFCR); and on Monday, May 2, at 9:00 A.M., at the Casino Theater on the Steel Pier.

The Seventeenth Annual Meeting of THE AMERICAN FEDERATION FOR CLINICAL RESEARCH will be held in Atlantic City, N. J., on Sunday, May 1, 1960, at 9:00 A.M., at the Casino Theater on the Steel Pier. On Sunday afternoon and evening, May 1, 1960, a joint sectional meeting with The American Society for Clinical Investigation will be held in rooms in the Chalfonte-Haddon Hall.

THE ASSOCIATION OF AMERICAN PHYSICIANS will hold its Seventy-Third Annual Meeting in Atlantic City, N. J., at the Casino Theater on the Steel Pier on Tuesday, May 3, 1960, at 9:30 A.M., and in the Vernon Room, Chalfonte-Haddon Hall, on Wednesday, May 4, 1960, at 9:30 A.M. 